JELTL (Journal of English Language Teaching and Linguistics) e-ISSN: 2502-6062, p-ISSN: 2503-1848

2020, Vol. 5(2)

www.jeltl.org

\title{
Learning through Watching: Using Animation Movie to Improve Students' Writing Ability
}

\author{
Dea Silvani \\ Universitas Siliwangi \\ e-mail: dea.silvani@unsil.ac.id
}

\begin{abstract}
Writing is often considered as a complicated skill to master. In order to be able to write effectively, there are several aspects to consider, which often make students face some problems in composing a written text. Thus, the use of the appropriate instructional media is necessary to help students overcome those problems, and enhance their writing ability. This classroom action research aims to investigate the improvement of students' writing skill through the use of animation movie as the instructional media. The participants of this research were two observers and 38 second grade senior high school students. This research used observation as the technique of collecting the qualitative data about the teaching and learning process, which then analyzed by using thematic analysis. Meanwhile, writing tests were used to obtain the quantitative data about the students' scores on the test given at the end of the cycles. Descriptive statistics are used to analyse the quantitative data obtained in this study. The research result showed that their average scores increased from the pre-test (75.68), to the post test in cycle 1 (78.71) and the post- test in cycle 2 (83.55). It indicated that their writing skill was also increased. Therefore, the use of animation movie in English class can improve the second grade senior high school students' writing skill.
\end{abstract}

Keywords: writing, animation movie, narrative text

\section{INTRODUCTION}

Foreign language acquisition is one of the most challenging process people may experience in their lives (Kabooha, 2016). Hence, they often face some challenges and difficulties when they are required to communicate by using foreign language. Meanwhile, in Indonesia, English is a foreign language that should be learned by the students from elementary school, up to university level. In this regard, to be able to communicate 


\section{Dea Silvani}

effectively students need to acquire adequate competence in the four language skills, which include listening, speaking, reading, and writing (Brown, 2000). Writing then is a means of communication that can be defined as a process that involves thinking and composing (Brown, 2000). Through writing students can formulate some ideas in their mind, then compose them in the written form. Thus, it enables them to deliver their ideas to the others (Hedge, 2008).

For making their writing more effective, students should have some specific criteria including spelling accuracy, correct use of capitalization and punctuation, appropriate use of grammar devices, meticulous choice of sentence structure and vocabulary for creating style and tone, as well as careful consideration in including appropriate information of their text (Hughes, 2003; Hedge, 2008; Heaton, 2003). By doing so, it enables them to hold a better communication, by which their ideas can be conveyed more effectively to the others.

However, writing itself is often considered as a difficult and complicated task to master (Heaton, 2003; Hedge, 2008, Zulfadlan and Arifin, 2013). Thus, students often find some difficulties when they are asked to write. On the other hand, the teachers also face some challenges in delivering an effective instruction for teaching writing. The result of observation and interview in preliminary study of this research showed that both the teacher and the students faced some problems in the process of teaching and learning writing. For instance, the students' were confused in deciding what information to include in their writing. When the teacher gave them a topic, and asked them to compose a short story, they did not have any ideas of what the content of their writing should be. Another problem is they could not organize the ideas well in their writing. When they were assigned to write a narrative text in the form of short story, they misplaced the introduction of characters involved and the place where the story took place in the middle of the story rather than in the beginning or in the orientation. Moreover, the researcher also found that they could not use correct grammar in their writing, since some of them used simple present tense, and present continuous tense in telling the story that occurred in the past, instead of using past tense. In addition, their lack of vocabulary mastery also becomes problem they faced in composing a text. Often, they did not know the appropriate word to express their ideas in English. Furthermore, the absence of interesting teaching media and the textbook style teaching methods that is normally implemented by the teacher could not attract students' attention and motivate them in learning to write. After all, in order to achieve the better learning result, those problems and challenges need to be solved.

Using animation movie as a media of instruction can be a solution to those problems. Several studies also find that animation movie can contribute positively in improving students' writing ability (Pandjaitan, Siringo-ringo and Hendriks, 2011; Ismaili, 2013; Kabooha, 2016; Ginting et al, 2019). Moreover, Baratta and Jones (2008) believe that movie is one of the more effective and appealing methods for engaging students in this generation. As a kind of audiovisual media, if it is carefully prepared by considering the learning objectives and students' proficiency level (Kabooha, 2016), animation movie can increase students' understanding, attract their interest to a topic being discussed, make the information they receive in the teaching and learning process last longer, and help the teacher to teach certain skill effectively (Kemp, 1963 as cited in Syafi'i, 2013). In the other 
words, in utilizing audio-visual media for teaching writing, teachers should consider the students' proficiency level and the appropriateness between the materials to deliver and content of the chosen media. Therefore, it can intensify students' understanding, escalating their interest in learning the target language, and support their memory to last longer. To sum up, audio-visual media is a very effective tool to use for teaching language skills if it is used appropriately. Hence, based on the afore-mentioned reasons, this research implemented the use of animation movie as the instructional media to improve students' writing ability.

\section{LITERATURE REVIEW}

Writing is a process which enables the exchange of ideas in the written form. It is a process of thinking and composing (Brown, 2000), which also involves communication (Hedge, 2008). Hence, writing process allows the students to communicate by formulating and organizing ideas by considering some aspects of writing to deliver those ideas to the audience/readers. In this regard, some writing aspects are important to consider by the student in order to be able to write effectively, which include content, organization, vocabulary, language use and mechanics (Hughes, 2003). Additionally, Hedge (2008) also mentions some criteria to write effectively including a high degree of accuracy, the appropriate use of complex grammar devices, a thoughtful choice of sentence structures and vocabulary to create tone as well as style, and to deliver appropriate information to the readers. Moreover, Heaton (2003) also suggests some necessary skills in order to produce a well composed writing, namely mechanical skill, grammatical skill, judgement skill, and stylistic skill. To sum up, in order master the ability to write effectively, the students should be able to include the relevant and appropriate amount of information into their written text. In addition, they should be able to clearly communicate their ideas, and to well organize them in a logical manner. Besides, they also need to acquire a broad range of vocabulary mastery and use language effectively by making use of correct grammatical rules, spelling, capitalization, and punctuation, so that the readers can understand the message or ideas being communicated in the written form.

Meanwhile, as a process, writing involves some stages. Those stages includes planning, drafting, editing and revising, and finally generating the final version (Harmer, 2004). In planning, the students formulate some main points of their writing which include the purpose, the audience and the organization of ideas. They can either make a specified note or simply write down some words, which reflect the general idea of their writing during this stage. The next stage is drafting. In this stage, the students may compose the initial version of writing. In general, the process of writing enables several draft productions, which then can be modified or developed before reaching the final version of the writing. After composing the draft, the next step of writing is editing and revising stage. Reorganizing ideas, evaluating the use of grammar and vocabulary, checking spelling, punctuation, and capitalization are some activities that can be done in this stage. Finally, after a number of modifications, the students will arrive at the final version, that has been modified, and serves at the final product of writing to share with the readers.

From the description above, it can be concluded that in communicating ideas through writing, the students should consider several aspects including content/information, organization of ideas, vocabulary choice, appropriate language use, and mechanics. 


\section{Dea Silvani}

Moreover, in order to compose an effective writing, they need to go through the stages of writing, starting from planning, drafting, editing and finally producing the final version. However, even though those aspects may serve as challenges in writing, the researcher believe that through regular practice, students' writing ability can be improved.

Accordingly, teaching English in EFL classes requires the teachers to spend more efforts for conducting successful language learning. For that reason, they should be able to help the students in solving the difficulties they face. By doing so, they can promote students' language mastery. Therefore, in conducting the instruction, teachers should use various media to support the effectiveness of teaching and learning process. Media themselves are the means for delivering instruction (Clark, 1983). They are components of learning sources or vehicles which contain learning materials, which in turn can encourage the students especially in language learning. They include any helpful instruments or devices that can be utilized by the teachers for assisting materials delivery.

However, even though there are numerous kinds of audio-visual media, this study focuses on the use of motion pictures or film/movie, especially animation movie as the instructional media. Motion picture is actually a moving image produced either from graphic presentation or live action (Ruis et al., 2009). Meanwhile, in specific, animation movie is a process to picture a character by relying on the ability to draw and imagine (William, 2007). Furthermore, animation in motion pictures is a technique, by which the producer makes use of persistence and constructs the effect which generate the illusion as if the inanimate object is alive and can make some movements (Brown et al, 1983 and Heinich et al., 2002). To sum up, animation movie is a kind of movie or motion pictures, which implements a technique that gives non-living things motion, in order to create an illusion as if they are alive. This technique can be carried out through a rapid exchange of pictures, drawn by an artist or a computer program.

Using animation movie in specific or audio-visual media, in general, brings about several advantages that can be utilized by both the teachers and the students especially in the process of teaching and learning to write. First, it can reinforce students' comprehension. Animation movie attract students' attention by enabling them to grasp the story easily, since it is commonly delivered through multiple means, including sound, language, expression, gesture and other visual clues. Thus, it can provide interesting as well as encouraging clues for the students to accompany audio or visual inputs, so that it is expected to support comprehension and production of foreign language that may help students' to develop their writing skills (Herron and Hanley, 1992). In other words, utilizing animation movie as learning source in teaching writing can enhance students' understanding, since the content is not only presented in the form of words, but it is also illustrated by using sound and image. Accordingly, Kasper (2002) states that it provides students a graphic illustrations of relevant content of information. Thus, animation movie, can also present beneficial information, which can be used by the teachers as the learning materials.

Furthermore, animation movie can attract students' sight, hearing and emotion, (Brown et al., 1983). Students can get the best and most interesting learning experience if they are involved both physically and mentally in the course of the story shown in the movie. Hence, animation move is able to enhance their focus, motivation, and interest in the subject being 
learned (Zulfadlan and Arifin, 2013 ; Ismaili, 2013). In addition, watching animation movie can inspire the students as it gives them various ideas to write, for it breaking through the time and space barriers, taking them venture into the past, present and future time, as well as into the imagination world (Brown et al., 1983; Kusumarasdyati, 2004; Zulfadlan and Arifin, 2013). Therefore, besides providing factual information, animation movie can also take the students to the imagination world, which in turn support their creativity in writing. It allows them to collect and organize many ideas to write because it does not have time and place limitation. Therefore, it serves as a very useful aid to assist students in mapping out or drafting what they will put into writing in the next stage of writing process.

Moreover, animation movie can enrich students' vocabulary mastery. it supplies experiences upon which vocabulary can be built (Brown et al., 1983), which in turn can help them in arranging the words to write a story (Zulfadlan \& Arifin, 2013). In this case, through watching animation movie, students can observe the language use, and the expressions spoken by the characters in order to gather new words or expression for enriching their vocabulary mastery. By doing so, it may also help them in communicating their ideas through the written text. Besides, watching animation movie also allows the students to observe the effective language use in real life contexts. It is one of the advantages of using audio visual media, since the students do not only listen to the language, but they can see it too (Harmer, 2001). Therefore, students can more explore the language used in the movie by perceiving the expressions uttered by the characters, in order to enrich their knowledge about the target language.

In conclusion, using animation movie as an instructional media brings about some advantages, which contribute positively, especially in teaching writing. Animation movie delivers the story through language, accompanied by multiple means, namely sound, image, gesture and expression, which improve students' comprehension of the learning materials. Besides, it can enhance their interest and motivation, since they can acquire more interesting learning experience. In addition, it can also help the students in writing, because it can provide some ideas and enrich their vocabulary mastery. Furthermore, animation movie allows the students to investigate the use of language in various contexts that can expand their insight about the appropriate use of language as a mean of communication. Therefore, the teachers should be able to carefully choose the appropriate animation movie, by considering the compatibility between the movie content and the learning material to be delivered. By doing so, it can effectively function in supporting the effective instruction.

\section{RESEARCH METHODS}

This research uses classroom action research method, which follows some stages namely planning, acting, observing and reflecting (Kemmis and McTaggart, 1988). Furthermore, observation and test are used as the techniques to collect the qualitative and quantative data.

\subsection{Participants}

The data participants of this research are 38 second grade students of a senior high school in Tasikmalaya, Indonesia. In addition, an English teacher and a colleague also participated in this research as peer observers. 


\section{Dea Silvani}

\subsection{Instruments}

To collect the qualitative data related to the students' and the teacher's behaviour during the instruction, this study employs observation sheets in the form of field notes as the instrument. Meanwhile, writing test is used as the instrument for collecting the quantitative data for measuring students' writing ability, especially in composing a narrative text.

\subsection{Data Analysis}

Interactive model by Miles and Hubberman (1984) is implemented in this study to analyse the qualitative data collected from the observation to the process of teaching and learning. This model consists of three steps including data reduction, data display and concluding or drawing verification.

Meanwhile, the quantitative data collected in this study came from the assessment of students' writing ability, which is evaluated based on five aspects of writing including content, organization, vocabulary, language use, and mechanic (Arthur, 2003). The data are then analysed by using descriptive statistics as follow:

a. Students' score

$\frac{B}{N} \times 100 \%$

Notes:

$\mathrm{B}$ : The score which is obtained

$\mathrm{N}$ : Maximum sore

b. The average of students' score

$\mu=\frac{\sum X}{N}$

Notes:

$\mu$ : The average of students' score

$\sum X$ : The total of students' score

$\mathrm{N}$ : The total of students

\section{FINDINGS}

This research aimed to investigate the improvement of students' writing ability by using animation movie as the instructional media. In general, this research consists of some cycles, by which each cycle has four stages, namely planning, acting, observing and reflecting.

In order to attain the aim of this research, the improvement of the students' writing ability can be seen by observing the result of their scores in the writing test, which is conducted at the end of every cycle. The result of the observation and test will decide whether or not the next cycle is necessary. If all of the students reach the Criteria of Minimum Completion (Kriteria Ketuntasan Minimal or KKM), in this case it is 77 for writing skill, it means that the research is successful, thus the next cycle is not necessary.

During conducting this research, several problems of writing faced by the students are found. Those problems are related to the content of the story, the lack of grammatical 
competence and vocabulary mastery. However, after using animation movie as the instructional media, the result of students' writing test at the end of the cycle shows an improvement.

Before the first cycle of this research was conducted, observation was done in preliminary study. It is found that most of the students got the low scores in writing test. There were only 14 of 38 students achieved the $K K M$, which means only $36.84 \%$ of the students achieved the Criteria of Minimum Completion, while the rest $63.16 \%$ or 24 students had not achieved the minimum completion score yet. Additionally, their average score was only 75.68, which is considered to be low. Hence, after considering the condition and the problems faced by the students, in order to improve their writing ability, animation movie is used as the instructional media in cycle I. In addition, during this research, the teacher implemented Genre-Based Approach (Callaghan and Rothery,1988; Green 1992; Cornish; 1992) as the learning method, which includes several steps namely (1) Building the Context, in which the teachers led the students into narrative text as the topic of the lesson by asking some questions and presenting some pictures, which were related to certain popular stories. The teacher also instructed the students about what they should do during teaching and learning process in order to give them brief overview about the learning activity, as well as the topic they are going to discuss; (2) Modelling and Deconstructing the Text, in which the teacher gave an example of the text to observe and analyze with the students; (3) Joint Construction of the Text, in which the students participated actively in writing the text based on the animation movie shown, and the teacher also guided the students to revise their writing; (4) Independent Construction of the Text, in which the students work independently in composing their own writing; and (5) Linking related Text, in which the students guided by the teacher investigated whether or not the text is related with certain genre used in the same field.

Having conducted the instruction in cycle I, then analysed the observation results, there were several weaknesses of the instruction coming from both the teacher and the students, as can be seen in Table 1. The first was the teacher's unclear explanation when she delivered the materials about lexico-grammatical features of narrative text. Second, the teacher did some unnecessary activities that can affect and bother students' focus during watching the animation movie. Third, the teacher only guided students who came forward and participated in composing the model text in front of the class to revise their works. Fourth, the teacher also skipped over the last stage of writing process, when she did modelling of the text in front of the class, which is producing the final version of writing. Fifth, the teacher could not well manage the time, since she was running out of time to go through every learning activities that had been planned before, which made her skipped a learning activity mentioned earlier. In addition, the students tended to be passive in taking part during the learning activities. Besides, some of them did not pay attention to the teacher when she delivered some explanations and instructions. To overcome the problems, some strategies were formulated, which could serve as the solution to support betterment in the next cycle as can be seen in Table 1 .

Meanwhile, the writing test results in cycle I indicated that $63.16 \%$ or 24 of 38 the students achieved the Criteria of Minimum Completion (77), while 36.84\% or the rest 14 students were unsuccessful in passing the minimum completion score. In addition, the sum 


\section{Dea Silvani}

of their total score was 2991, which made their average or mean score in general was considered to be low, since it fell in 78.71.

The research result shows there were 14 students whose scores were still under the $K K M$. In the other words, not all of students could achieve Criteria of Minimum Completion (77). Besides, the mean of students' score is still low. In addition, there are also seven weaknesses found in cycle I that need to be solved in order to improve the practice of teaching and learning process in the next cycle, as can be seen in Table 1. It can be done through conducting a better instruction manifested in the lesson plan. For that reason, cycle II was then necessary to take place because the process of teaching writing by using animation movie as the instructional media was considered to be unsuccessful.

Table 1 Weaknesses and proposed solutions of the teaching and learning process in cycle I

\begin{tabular}{|c|l|l|}
\hline No & \multicolumn{1}{|c|}{ Weaknesses } & \multicolumn{1}{|c|}{ Solutions } \\
\hline 1. & $\begin{array}{l}\text { The teacher's unclear explanation about } \\
\text { lexico-grammatical features of narrative } \\
\text { text. }\end{array}$ & $\begin{array}{l}\text { The teacher should explain the lexico- } \\
\text { grammatical features more clearly by giving } \\
\text { more examples to the students. }\end{array}$ \\
\hline 2. & $\begin{array}{l}\text { While watching the movie, the teacher } \\
\text { walked around the class and cleaned the } \\
\text { blackboard, so the students focus was } \\
\text { distracted }\end{array}$ & $\begin{array}{l}\text { It will be better if the teacher does not do } \\
\text { unnecessary movements to maintain students' } \\
\text { concentration during the movie watching. }\end{array}$ \\
\hline 3. & $\begin{array}{l}\text { The teacher only gives personal guidance } \\
\text { to the students who participated in } \\
\text { composing the model text in front of the } \\
\text { class to revise their own works without } \\
\text { involving the rest of the class. }\end{array}$ & $\begin{array}{l}\text { The teacher should involve all of the students } \\
\text { to edit the model text, which is composed by } \\
\text { some students in front of the class, so the } \\
\text { whole class will know how to edit the writing } \\
\text { draft. }\end{array}$ \\
\hline 4. & $\begin{array}{l}\text { The teacher did not ask the students to } \\
\text { write the final version of the short story in } \\
\text { front of the class, in the stage of Joint } \\
\text { Construction of the Text. }\end{array}$ & $\begin{array}{l}\text { The teacher should ask the students to write a } \\
\text { shorter and simpler text, so this activity can be } \\
\text { accomplished without wasting much time. }\end{array}$ \\
\hline 5. & $\begin{array}{l}\text { The time for the lesson was over, while } \\
\text { the learning activities have not finished. }\end{array}$ & $\begin{array}{l}\text { The teacher should manage the time for each } \\
\text { learning activity better. }\end{array}$ \\
\hline 6. & $\begin{array}{l}\text { Some students did not actively involved } \\
\text { in the teaching and learning process. }\end{array}$ & $\begin{array}{l}\text { The teacher should encourage the students to } \\
\text { join actively in the learning activity, for } \\
\text { example by encouraging them to be brave and } \\
\text { telling them not to be afraid of making } \\
\text { mistakes. }\end{array}$ \\
\hline 7. & $\begin{array}{l}\text { Some students did not pay attention to the } \\
\text { teacher's explanation. They did the other } \\
\text { activities, such as using their cell phones } \\
\text { and chatting with their friends. }\end{array}$ & $\begin{array}{l}\text { The teacher should assert and remind the } \\
\text { students to pay attention, so that they can be } \\
\text { more focused in joining the learning process. }\end{array}$ \\
\hline
\end{tabular}

Having conducted cycle II, the observation result of this cycle showed that the entire problems emerged in cycle I related to the process of teaching and learning could be overcome by carrying out the solutions proposed at the end of cycle I as can be seen in Table 
1. Overall, the teacher and the students could solve those problems in the previous cycle during conducting the instruction in cycle II. Therefore, the process of teaching and learning writing in this cycle ran more effectively.

The result of the students' writing test indicated that all of 38 students (100\%) could reach the Criteria of Minimum Completion (KKM). Besides, their average or mean score also improved to be 83.55, as the result of the sum of their total score that increased to 3175 . Moreover, the students performed the better attitude in joining the instruction. Furthermore, the class situation was more conducive as the students were more focussed on learning to write narrative text. Therefore, teaching writing by using animation movie as instructional media was successful as it can improve students' ability to write a narrative text.

\section{DISCUSSIONS}

In general, the research result shows a prominent improvement of students' writing ability by using animation movie as the instructional media used in teaching writing. It can be seen from the result of the writing tests, which indicate that their writing scores in cycle II increase from those in cycle I. In addition, the result of observation shows that students performed the better learning attitude in joining the instruction.

The result of this research also denoted that the students faced some difficulties when they are assigned to write a text. In line with this, there are eight common problems usually faced by the students in writing, including problems with commas, other punctuation issues, apostrophe, subject-verb agreement, sentence structure, word usage, commonly misused expressions and general style issues (Hensel, 1996). During the writing activity, it is found that they often faced some problems related to the mechanics aspects, such as the use of inappropriate punctuations, and incorrect spelling of the words. Additionally, they also made some mistakes in using the language, for instance they used incorrect subject and verb agreement, and wrote incorrect sentence structure. Moreover, the limited range of vocabulary also determined their word choice for expressing their thoughts and ideas in the written form. However, those problems can be reduced by using animation movie as instructional media.

From the result of writing test at the end of cycle I, $63.16 \%$ or 24 of 38 students could achieve the score of Criteria of Minimum Completion or $K K M$ (77), with 78.81 as their average score. Whereas, at cycle II all of the students (100\%) were successful in achieving the $K K M$ (77), which resulted in their mean score that also rose into 83.55. In this case, their learning achievement can be affected by the benefits of using animation movie as instructional media. As a kind of motion pictures, animation movie is capable of enhancing students' comprehension of the material being learned (Kasper, 2002). It means that this media, which presents moving pictures, may contain pertinent information related to the learning materials. Moreover, in this research students also acquired the knowledge about the target language from watching the animation movie, since it presents moving pictures along with sound that carries relevant information concerning the learning materials. Accordingly, Herron and Hanley (1992) also believe that film can help students to develop their writing ability by serving interesting and motivating hints to escort audio and written inputs for assisting foreign language comprehension and production. 


\section{Dea Silvani}

Additionally, through watching animation movie, the students may collect some ideas to write, since it has no time and space limitation, which enables the audience to venture into the past period, present situation, future time, and into the world of their imagination (Brown et al., 1983; Zulfadlan and Arifin, 2013; Kusumarasdyati, 2004). This media can present a vast range of topics, which are expected to inspire the students to develop their imagination and creativity. Therefore, they can gain a number of ideas to write (Zulfadlan \& Arifin, 2013). Morever, Lestari, Leoneto and Ihsan (2019) believe that in writing class the students are required to have good logic in expressing the ideas. By watching the course of the story presented in the animation movie, the students can have better understanding related to the structure of narrative text, which in turn, can help them to arrange their ideas in a logical manner. It is in line with a result of a study conducted by Pandjaitan, Siringo-ringo, and Hendriks (2011), which denotes that animation movie contributes in helping students to understand the structure of narrative text, and encourage them to start writing.

Furthermore, Lestari, Leoneto \& Ihsan (2019) also suggest that students need to add their vocabulary in writing class. In this regard, watching animation movie enables the students to enrich their vocabulary mastery, through observing the language used in the movie itself. It is in line with a finding from a research conducted by Kabooha (2016), which revealed that movie could help students improve their vocabulary mastery, because they provide a large amount of information about a variety of vocabulary, colloquial expressions, and phrases. It is also in line with the finding from Tognozzi's study in 2010, which discovered that film also enables the students to have cultural awareness, since the students can observe how language is used for communication in real contexts. Accordingly, Harmer (2001) states that by watching video, students do not only hear the language used, but they may also observe it visually. In this present study, during the instruction in both cycles, students watched animation movie shown by the teacher, while they were also asked to investigate the language use in the movie. Since it conveys the content and the language through sound and images, watching animation movie enables the students to enrich their vocabulary mastery and expand their grammatical competence by also considering the notion of culture, which in turn can help them improving their knowledge and communication skill, especially in writing. It is also supported by a study conducted by $\mathrm{Li}$ and Wang (2015), which also found that movie can expand students' knowledge and enrich their vocabulary mastery.

Moreover, there is also a pertinent enhancement of students' writing achievement, which is assessed through writing test given at the end of every cycle after the use of animation movie as the instructional media. In specific, the research results show that students ability in writing improved as their score in the assessed aspects of writing that include content, organization, vocabulary, language use, and mechanics (Arthur, 2003) also increased. Therefore, using animation movie as instructional media is very effective to help students improve their writing ability, as it provides some advantages that can reduce and overcome students' writing problems.

In addition, the observation results from cycle I and cycle II also reveal some benefits brought by the use of animation movie as the medium of instruction towards the teaching and learning process. First, watching animation movie encourage the students to be more 
focused and active in joining the instruction. Some studies have found that movie/film is considered as an effective motivator in language learning (Seferoğlu, 2008; Ruusunen, 2011; Ismaili, 2013). Moreover, a study conducted by Kusumawardhani and Nurhayati (2019) found that most of the students were happy and enthusiastic when they were ask to watch a movie. Accordingly, in their study, Zulfadlan and Arifin (2013) also noted that the learning atmosphere was more comfortable and enjoyable after they utilizing animation movie in teaching writing. In this regard, animation movie as a kind of motion pictures is able to communicate the content directly to students' minds, emotions, sight, and hearing (Brown, et al., 1983). Thus, it can hold their attention (Tognozzi, 2010), which makes their concentration last longer in joining the learning activities. As a rseult, in this research, the classroom atmosphere is better and more enjoyable, as it makes the students involve emotionally while watching the course of story. For those reasons, animation movie as a kind of audio-visual media, if it is carefully prepared by the teacher, can add students' interest in the topic being discussed, (Kemp, 1963 as cited in Syafi'i, 2013), which in turn can also improve students' positive attitude towards the course (Akerele. Ayodeji and Adeola, 2012) that can support the effective teaching and learning process. Hence, Dj and Sukarnianti (2015) suggest that the teachers should choose an interesting teaching strategy to attract students' attention, and make the students learn more comfortably. As animation movie delivers the content through sound and images, it can also give a new learning experience for the students. Moreover, previously, the teacher usually taught by using textbook style, and neglecting the use of audio-visual media. Therefore, using animation movie can make them more enthusiastic and focus in learning to write.

However, this research also found that the result of students' improvement was also determined by the teacher's role while conducting the instruction. Unfortunately, observation in cycle I shows that there were some weaknesses related to teacher's competencies. Meanwhile, there are actually four competencies that should be owned by a good language teacher including personal qualities, technical knowledge, interpersonal skills, and pedagogical skills (Brown, 2000). In cycle I, some weaknesses were found at the level of the teacher's pedagogical skills. For instance, she delivered unclear explanation about lexicogrammatical features of narrative text. As a result, the students could not acquire the appropriate amount of information as the preparation for producing a good writing. Then in cycle II, the teacher explained the materials in more detailed, so that she could ensure that the students got the information needed for composing their own writing in the next stage of learning, since the teacher should be able to perceive effectively students' linguistic needs (Brown, 2000). In addition, she also accompanied her explanation by using presentation slides and gave adequate examples for every lexico-grammatical features of narrative text. By doing so, the students could acquire a better understanding about the learning materials, as the teacher used the effective and clear presentation skill (Brown, 2000). As a result, those points can affect the students' achievement in the writing test, which is shown in the result of their writing test that improved from the previous cycle.

The other problem found during the instruction in cycle I is the lack of teacher's classroom management. In this case, some students were stuck with their own activities such as using their mobile phones. As a result, they did not listen to the explanation given by the teacher. Meanwhile, managing the students and controlling the class is one of the basic skills 


\section{Dea Silvani}

of teaching (Harmer, 2001). Accordingly, the teachers should be able to use the appropriate principles in managing the class (Brown, 2000). It requires the teachers to have the ability of creating effective and conducive classroom situation during conducting the instruction. Hence, it was suggested that the teacher should be able to manage the students more assertively, by addressing students who did not focus to her explanation, which is expected to help them gaining the better understanding about the learning materials.

In addition, observation in cycle I also noted that the teacher did some unnecessary activities during watching animation movie, which could interrupt students' focus. While Harmer (2001) believes that the students can be exhausted in focusing their concentration if the teachers keep moving constantly during the teaching and learning process. Therefore, she restrained her movement, and only did necessary things in order to maintain students' focus during the instruction.

Besides, the teacher unfortunately skipped over a learning activity, which had been included in the lesson plan in cycle I. She did not ask the students to compose the final version of their writing, when they were in the stage of Joint Construction of the Text. Meanwhile, a good language teacher should be able to effectively design and execute the learning activities stated in the lesson plan effectively (Brown, 2000). Thus, in the next cycle, the teacher could solve the problem, and execute all of the learning activities as formulated in the lesson plan. In addition, she also did not involve the whole class to revise the model text composed by some students in front of the class. Instead, she only guided students who voluntarily came forward and composed the model text to edit their works, without letting the others to also learn from their friends' mistakes. On contrary, a good language teacher should give optimal feedback to the students during the learning process (Brown, 2000). It is also supported by Ariyanti (2016), whose study tries to investigate some fundamental aspects for shaping students' writing ability. In her study, she suggests the teacher to understand that writing actually involves some activities including practicing, having guidance and also giving feedback from the teacher. Moreover, a study conducted by Aunurrahman (2019) reveals that students, who believe that the teacher and their friends can help them improve their writing ability, will become more confident to write. Therefore, in cycle II, the teacher involved all of the students in revising the draft of the model text composed by their friends. Besides, she guided the students one by one, and gave appropriate amount of feedback towards their writing. By doing so, she could monitor the students' progress and help them with their writing difficulties. Hence, it also supported the improvement of students' writing ability. To sum up, after using animation movie as instructional media in teaching writing, not only the improvement of students' writing ability and learning attitudes that affect the success of teaching and learning process, but also the enhancement of teacher's ability in conducting the instruction. It is in line with a suggestion from $\mathrm{Dj}$ and Sukarnianti (2015) in their research, that in order to improve the quality of teaching writing, the teachers should improve their knowledge and ability in teaching. In other words, they need to consider the appropriate materials to deliver and method to apply in their teaching so that it can help the students overcome their writing problems and promote them to be well-qualified writers in the future (Banu, Benu \& Wulandari, 2018). As a result, those aspects give positive contribution to attain the expected learning result. 
In conclusion, animation movie is a beneficial media that can be used by the teachers in teaching writing, since it brings about some advantages that can support the effective teaching and learning process, and improve students' writing ability. However, they need to carefully choose the appropriate animation movie by considering the content of the movie to meet the suitability with the materials or topic of the lesson. Additionally, Pandjaitan, Siringo-ringo and Hendriks (2011) in their study also suggest the teachers to choose the interesting or popular movies with simple plot and fit to the core material. By doing so, it can help the students to obtain a better understanding, and promote more interesting and enjoyable learning experience. This research results verify that using animation movie as the instructional media can increase senior high school students' writing ability. It is proven that in the end of cycle II, the entire class scored over the Criteria of Minimum Completion (77), and their average score also increased to 83,55. Moreover, animation movie can support the effective teaching and learning process which leads the students to attain the better learning outcome.

\section{CONCLUSION}

This study This study aimed to investigate the improvement of students' writing ability through using animation movie as instructional media in English class in senior high school level. The result of this study shows that using animation movie as instructional media brings about some advantages that can solve students' difficulties related to the writing aspects including content, language use, organization, and vocabulary. This research is conducted in two cycles, cycle I and cycle II. At the end of this research, the result of cycle II shows that students' average score in general, and their individual score in specific significantly increased compared to the result of cycle I. Additionally, using animation movie as instructional media can encourage them to have a better attitude in joining the process of teaching and learning. Nonetheless, the observation result of cycle I showed that several weaknesses emerged during the instruction, which came from both the teacher and the students. Those weaknesses namely the teacher's unclear explanation, teacher's unnecessary activities during watching the animation movies that interrupted students' concentration, teacher's preference on only guided the students who came forward to edit their works and ignoring those who did not, teacher's careless in skipping one of the writing stages, and her lack of classroom management. In addition, the students tended to be passive in participating during the instruction, and some of them were busy with their own activities and did not pay attention to the explanation given by the teacher. After all, those weaknesses could be overcome in cycle II by applying the proposed strategies, which were formulated in cycle I. As a result, applying those strategies also contributed in improving students' ability to write a narrative text. In conclusion, the use of animation move as the instructional media can help the students to solve their writing problems and improve their writing ability.

\section{REFERENCES}

Akerele, J. A., \& Afolabi, A. F. (2012). Effect of video on the teaching of library studies among undergraduates in Adeyemi College of Education, Ondo. Library Philosophy and Practice, 1522-0222. 


\section{Dea Silvani}

Ariyanti, A. (2016). The teaching of EFL writing in Indonesia. Dinamika Ilmu, 16(2), 263277. https://doi.org/10.21093/di.v16i2.274

Aunurrahman, A. (2019). Exploring writing anxiety of the EFL university students in Pontianak Indonesia. IJELTAL (Indonesian Journal of English Language Teaching and Applied Linguistics), 4(1), 109-119. http://dx.doi.org/10.21093/ijeltal.v4i1.336

Banu, T. B. J., Benu, S. V. C., \& Wulandari, H. (2018). Students' objective needs in learning to write: An overview on the EFL teaching and learning practice. IJELTAL (Indonesian Journal of English Language Teaching and Applied Linguistics), 3(1), 125-139. http://dx.doi.org/10.21093/ijeltal.v3i1.141

Baratta, A., \& Jones, S. (2008). Using film to introduce and develop academic writing skills among UK undergraduate students. Journal of Educational Enquiry, 8(2), 15-37.

Brown, H. Douglas. (2000). Teaching by Principles. London and New York: Longman.

Brown, J. W., et al. (1983). AV Instruction. New York: McGraw Hill.

Callaghan, M., \& Rothery, J. (1988). Teaching factual writing: a genre-based approach: the report of the DSP Literacy Project, Metropolitan East Region. Metropolitan East Disadvantaged Schools Program.

Clark, R. E. (1983). Reconsidering research on learning from media. Review of Educational Research, 17 (2), 92-101. https://doi.org/10.3102/00346543053004445

Cornish, S. (1992). Community access: Curriculum guidelines. Curriculum Support Unit, NSW Adult Migrant English Service.

Dj, M. Z., \& Sukarnianti, S. (2015). Using hypnoteaching strategy to improve students' writing ability. Dinamika Ilmu, 15(2), 185-199. https://doi.org/10.21093/di.v15i2.101

Ginting, K., Syafitri, D., Nehe, C., Manullang, N., \& Tarigan, S. (2019). Improving students' skill in writing narrative text through animation movie. Linguistic, English Education and Art (LEEA) Journal, 3(1), 230-237. DOI : https://doi.org/10.31539/leea.v3i1.1000

Green, J. (1992). Making the links. Melbourne: AMES Victoria.

Herron, C. A., \& Hanley, J. (1992). Using video to introduce children to a foreign culture. Foreign Language Annals, 25(5), 419-426. https://doi.org/10.1111/j.19449720.1992.tb01122.x

Harmer, J. (2001). Practice English Language Teaching. London: Longman.

Harmer, J. (2004). How to Teach Writing. London: Longman.

Heaton, J.B. (2003). Writing English Test. 6th Ed. United States of America: Longman. Inc.

Hedge, T. (2008). Writing. Oxford: Oxford University Press.

Heinich, R. et al. (2002). Instructional Media and Technologies for Learning. USA: Merrill Prentice Hall.

Ismaili, M. (2013). The effectiveness of using movies in the EFL classroom - A study conducted at South East European university. Academic Journal of Interdisciplinary Studies, 2 (4), 121-13. DOI : 10.5901/ajis.2012.v2n4p121

Kasper, L. (2002). The imagery of rhetoric: film and academic writing in the disciplinebased ESL course. Teaching English in the Two-Year College, 28 (1), 52-59.

Kusumawardhani, P., \& Nurhayati, N. (2019). The analysis of teaching writing to English young learners (EYL) through a Movie: An ICT Perspective. Wanastra: Jurnal Bahasa dan Sastra, 11(1), 25-36. https://doi.org/10.31294/w.v11i1.5065 
Kabooha, R. H. (2016). Using movies in EFL classrooms: A study conducted at the English Language Institute (ELI), King Abdul-Aziz University. English Language Teaching, 9(3), 248-267. DOI: 10.5539/elt.v9n3p248

Lestari, D. E., Loeneto, B., \& Ihsan, D. (2019). The correlation among English learning anxiety, speaking and writing achievements of senior high school students. Indonesian Journal of EFL and Linguistics, 4(2), 135-150.

Li, X., \& Wang, P. (2015). A research on using English movies to improve Chinese college students' oral English. Theory and Practice in Language Studies, 5(5), 1096-1100. http://dx.doi.org/10.17507/tpls.0505.26

Pandjaitan, N., Siringo-ringo, E. G., \& Hendriks, A. L. (2011). A Study on the effectiveness of using animation movie compared to conventional method in teaching narrative writing. Journal of Language Pedagogy, 1(2), 69-81.

Ruis, N. et al. (2009). Instructional Media. Jakarta: Ministry of National Education.

Ruusunen, V. (2011). Using movies in EFL teaching: The point of view of teachers. Unpublished Master Thesis. Department of Languages. University of Jyväskylä.

Syafi'i, A. (2013). Using cartoon movies in process genre based approach to improve the ability of the eighth year students of SMP Wahidayah Kediri in writing narrative text. Journal Language Edu, 2 (2), 220-227.

Seferoğlu, G. (2008). Using feature films in language classes. Educational studies, 34(1), 19. doi: 10.1080/03055690701785202

Tognozzi, E. (2010). Teaching and evaluating language and culture through film. Italica, 87 (1), 69-91. doi: 10.2307/20750678

Zulfadlan, A., \& Arifin, T. M. (2013). Improving grade X students' achievement in writing narrative paragraph through animation movie. Journal of English Language Teaching of FBS-Unimed, 2(1), 1-16. 